\title{
N.I. Rudenko
}

\section{NEW MEDIA AND CITIES: THREE LOGICS OF INVESTIGATION AND IMPLEMENTATION}

Sociological Institute of Russian Academy of Science; European University at Saint Petersburg

This paper deals with urban new media - computer technologies in forms of applications, programs, and some arrays of scripts, which automatically create actions or provide some complex services for different social groups in a city. It is assumed that processes of development, implementation and investigation of urban new media are in a situation of controversy since nobody knows on what principles they should be based upon and what aims to pursue. In this article we offer three logics (A. Mol), ratios and mutual mechanisms of affinities that are proper to some practices, that we can discern in the current process of development of urban new media. The communal logic aims at association of people and creating a shared platform for communication and knowing some aspects of cities. The critical logic aims to dissociate and sift certain groups of people from population as whole and make profit out of users. Finally, cosmopolitical logic (I. Stengers) is associated with intention to include many heterogeneous actors into process of discussion and making decisions for creating "sense" of some urban space or aspect. In the conclusion, we ponder upon how the aforementioned logics could be implemented practically to spur the communication between the authorities and publics in Russian monotowns. Refs 29.

Keywords: Urban new media, communal logic, critical logic, cosmopolitical logic, applications.

\section{НОВЫЕ МЕДИА В ГОРОДАХ: ТРИ ЛОГИКИ ИССЛЕДОВАНИЯ И ВНЕДРЕНИЯ}

\section{Н.И. Руденко \\ Социологический институт РАН; \\ Европейский университет в Санкт-Петербурге}

В данной статье описываются новые медиа в современных городах - цифровые компьютерные технологии в виде приложений, программ, или набора скриптов, которые автоматически совершают действия или обеспечивают услуги для разных социальных групп в городе. Предполагается, что процессы разработки, внедрения и связанные с ними процессы исследования возможностей новых медиа находятся в ситуации контроверз, когда никто не знает, какие принципы должны быть заложены в новые медиа в городах и какие цели должны с помощью них преследоваться. Мы предлагаем три логики (понятие социолога А. Мол), т. е. выстроенных соотношений и взаимных механизмов схожести, свойственных практическим действиям, которые можно выделить в настоящих процессах разработки новых городских медиа. Логика сообщества имеет своей целью ассоциацию отдельных групп и создание общей платформы для коммуникации и познания отдельных сторон города. Критическая логика ставит своей целью, наоборот, диссоциацию и «просеивание» с помощью технологий отдельные группы, чтобы отделить их от всего остального населения. Наконец, космополитическая логика (понятие философа И. Стенгерс) связана с интенцией включить гетерогенных акторов в процессы дискуссий и принятия решения относительно создания определенных смыслов в отношении городского пространства. В заключение мы даем краткие замечания в отношении того, как вышеупомянутые логики могут быть использованы практически, чтобы стимулировать коммуникацию между властью и жителями в современных российских моногородах. Библиогр. 29 назв.

Ключевые слова: новые городские медиа, логика сообщества, критическая логика, космополитическая логика, приложения. 


\section{Introduction}

In the beginning of 2016 first vice-premier of the Russian Federation Igor Shuvalov gave charge over Monotowns Development Fund to create a digital platform for communication between business community, citizens, and local authorities in Russian monotowns.

The foundation for this platform will be popular Russian social network "Vkontakte". According to Shuvalov, this project 'gives capacity to the Russian Government to track and influence implementation of monotowns developments projects' because traditional forms of communications and feed-backs were acknowledged as ineffective [1]. This decision was considered as problematic not only in the press but also in the Parliament where some deputies criticized it for being superficial, unnecessary, and unsafe [2].

We would like to consider this governmental initiative not as an issue about governmental capacities of social networks (and clearly not as a case for detailed analysis this article addresses), but as an example of appreciation of new media, that is, social networks, digital platforms, applications, by remarkable stakeholders. And what is more important, this case concerns new media in urban spaces generally. Not only deputies have doubts of possibilities of new media, but also many other actors: developers, policy makers, businessmen, scholars. We assume that, despite proliferation both new media in cities and literature of all kinds about them, they are now in controversy situation where nobody knows what are they, what aims that should pursue and how to perceive their relations with urban spaces [3].

Under new media [4] we mean computer technologies in forms of applications, programs, and some arrays of scripts which automatically create actions or provide some complex services for some social groups in a city. City in one way or another is important actor, explicated or not, for acting out of these programs. Examples are manifold. Social apps, date apps, apps for communication, apps for finding new places, and for enhancing the experience, touristic in particular.

Scholars tend to emphasize that new media challenge the way we sense urban space $[5,6]$. Cities become flows of information and contacts. They give citizens the possibility to change many places. They rearrange ways of behavior - one can decide where to go based on abrupt messages of events, location of people, new places they have never known until recently. Some scholars successfully demonstrate that in certain countries smartphones became the first way of using Internet for adolescents, and it changes the situation in communication practices in total: keitai (analogue word to smartphone) for Japanese school kids become a necessary thing to carry out with [5]. Touristic experience also is now widely mediated through special applications [7].

Again, despite the increasing amount of new media in cities, it seems that we've found ourselves in situation of controversies since nobody knows for sure on what principles they should be based upon, especially when it concerns social, ethical and political issues. Science and technology studies (STS) approach cogently showed that technologies could not be easily detached from social relations, and that technological artifacts always were non-human partners in human history, mediating all human issues [8]. If so, what shall we do with new media that surround cities all over the world, changing our communication, transportation, and production? It is a triple-headed question since it aims at developing, Investigation, and policymaking dimensions. 
In what follows, we would like to present our vision of three logics that penetrate the processes of development, investigation, and implementation of new media that are used in cities and which we may call "urban new media". These logics are neither principles nor rules or norms, but exactly logics - ratios and mutual mechanisms of affinities that are proper to some practices [9]. To some extent they could be seen as cosmograms, recalling the concept of John Tresch, that is, some visual or discursive orderings of sociotechnical assemblage that cover in the nutshell ontology of that assemblage [10]. We would like to note that these logics are not created from scratch, but are superpositions of ideas, mediations, practices assembled from urban theory, sociology, political science. Toward the situation with urban new media, we claim that it is time to be quite "idiotic" (in Isabelle Stengers'sense) to ask as many as we can stupid questions about common world where we live today with digital technologies [11]. Regarding the latter, we should be like main protagonists of Samuel Becket's play "Waiting for Godot" not to go anywhere although it seems that it is time to.

\section{Review of the relevant scientific literature}

Efforts were made to discern some politics out of development and implementation of new media in urban spaces. One of those is Graham and Crang's article about contrasting visions of an digital urban environment [12]. They distinguish four main conceptualizations of what happens today with urban space: the latter becomes augmented, enacted, transductive or blogjective [12]. All these concepts have their own defenders from scholars, but it seems for authors that they are too myopic or biased not to see the political consequences of them. All of them, in one way or another, aim at blurring boundaries between informational and physical spaces (what might be called "hybrid spaces" after de Souza e Silva [5]). Differences lie in to what extent they conceptualize this blurring. Advocates of augmented spaces see changing as superimposition of information screens on physical spaces (like through glasses): with the help of it one can see additional information or media object on ordinary objects (for instance, one can look at hotel building and see information about costs of living there). Enacted urban spaces occur when electronic chips and computer processors are sewed in everyday objects: as a result, one can control these artifacts with smartphones or computers. The internet of things in action! Finally, 'transductive' and 'blogjective' spaces imply speculative realist stance toward non-human relations of artifacts and spaces: with the help of code or even without it artifacts and spaces may communicate with each other to create new interesting topologies. Let's imagine videogame random-generated landscape to be embodied in urban mundane reality!

All of these concepts and prototypes are good, but what political consequences sill they have in the future? Graham and Crang discern three main areas where fantasies about ubiquitous computing, blurring of physical and informational spaces, emerge: market, military services and urban art. They are strong frames, which transform musings into concrete practices of marketing-consuming, security and reanimating the city. These areas are not just practical issue, but also important devices for thinking about urban space: 'all of these offer significant contributions to thinking about both what the urban environment might become but also into how we think about it' [12]. The authors underline one great problem with all these contemplations about ubiquitous technologies and their implementation: one of passivity of users: 'This, of course, risks to delegate whole sets of 
decisions and, along with that, the ethics and politics of those decisions, to invisible and sentient systems which both blur seamlessly into local, urban environments, and enact and organize global and transnational flows' [12]. And they would like to find a solution of this issue in multiplying information islands to create city made of many spaces that is close to De Certeau's concepts of everyday practices which cannot be reduced to some overall from top to down logic.

With a large share of sympathy to these findings, we would not like to multiple spaces in the city but to multiple logics of new media in it. What if the passivity of users is part only of one logic we can outline? What could be other alternatives to that vision (for instance, to make users omnipotent, to make users and non-users are equal)? What urban and STS theories and practices of implementation could offer us to see new media in city in very different ways. What if they could be otherwise, calling to mind the famous STS motto [13]?

\section{Critical review of the theoretical approaches}

One of the best ways to start pondering upon new possible technological logics is newspapers [14]. Or news websites, if we are living in today where digital media take over control. When we're encountering news about innovative technologies, especially IT, clarity is going to disappear. Big Data Lab, part of Chinese corporation Baidu, created an algorithm that gives possibility to predict gathering of crowds of people. It also warns "organizations and private persons" about threats of public security [15]. The reason for creation such a program is clear: there's a problem with crowds in China and many people hurt sometimes. But the most curious part is an attempt of speaker of Big Data Lab to persuade public that there is no politics in such software and it will be used only to help to control crowds, but not to scatter political demonstrations and meetings. Although it could be true, shadow of political authoritarianism and control issues rise above this technological initiative.

Another case is famous platform Instagram. From its outset in 2010 Instagram functions as one of the most extending informational networks that let many people all around the world create, edit, share and comment photos they make by their smartphones. There is no convention what Instagram is, and we can see two opposite logics in academic papers. Some researchers write that Instagram is "participation platform", some kind of diffusive shared sensing system which permits to snap different part of cities and to represent it to other users. One can imagine an aspiring picture of millions of active people who work with each other in an indirect way to help to permanently see a city and to understand its multiple facets. Participatory sensing is a very useful concept here: 'participatory sensing is the process where humans actively use mobile devices and cloud computing services to share local environmental data such as a picture' [16]. Political imaginary of Instagram is that it is common business of many people not to represent but also to make their city better. Although it could be very persuasive, there is another image of Instagram, opposite one. In 2014 Instagram faced some transformation: "selected brands have been able to pay for sponsored posts targeted at specific users" [17]. The authors of article about brands and Instagram see the latter as "an image machine that captures and calibrates attention" [17]. Millions of photos that are made every week are just permanent "image flow". What the role of users here? They make photos, but it is not what could be seen as the most im- 
portant. They passively look through photos, that's more important. Marketers of global corporations are very well aware of it. That's why they use native advertisement posts nowadays - to capture and calibrate attention. The latter is what the most important in Instagram, because it could increase purchases. Instagram is neither participatory system, nor political project of shared cognition of active users, it is image machine that forces the hand of many passive consumers to buy more.

This and many other cases show that many local forces have their own decisions to what new media should be. And actually nobody knows what are they since they are in controversy situation appearing from one or another angle. Nevertheless, we can discern some logics, some inexplicit ratios, or systems of affinities, crossing all these different spaces. These logics are multiple, but we would like to point at three of them that we suppose the most remarkable ones. They are, to repeat, not just abstract rules or thoughts we can adjust to technical devices, but seamless networks of affinities of some traits and parts that make particular sociomaterial ordering to emerge. Without having exact and more proper words, we can call these logics communal, critical and cosmopolitical. In what follows, we would like to distinguish some of their traits.

\subsection{The communal logic}

In a nutshell, we might say that three logics meets three important features of new media. They could be describe in such ways: firstly, new media technologies are able to connect people (recalling famous Nokia advertisement) and assemble them and their artifacts in new ways. In this sense, they are alternatives to older social forms (gender, class, ethnicity) since they can unite many people who don't know each other to new complex sociotechnical assemblages. Secondly, they have ability to accumulate and keep data from different sources, as well as rearranging it in new different ways. Thirdly, they are able to represent many different views and interests on one (interactive) map or screen. All three issues: social associations, tracking and keeping data, and representation of the urban multiplicity of actors are important as well as for citizens and urban scholars as for policy makers and authorities.

Communal logic focuses on social and 'collectivistic' feature of urban space, and renders new media as a tool for a help to gather many people around multitudes of issues. People are the most important part here, but only people who belong to particular infrastructure. They are able to be empowered by new technology either to do what they did some times ago (but can't do now) or to do something new they have never envisaged. Today, as developers of new media say, we find ourselves in a situation of anomie, alienation, lack of previous sociability. Old forms of connections between people are impossible in a situation of megalopolises, where too many people and they are too mobile to know each other well. Here one may find the situation of the rooming houses, perfectly described by Harvey Zorbaugh, are stretched out to big modern cities in total [18]. People do not know their own neighbors and it causes problems in making contacts, partaking in some important events or keeping security. That's where new media can take over control. Two years ago the world event was founded pertaining to urban applications called "AppMyCity-2014" [19]. It was created as competition between app developers for making the most useful urban app. The first prize was won by an Amsterdam developer with his "Peerby" application that permits borrowing and changing tools and facilities (drills, saws, ladders, trailers, moving boxes, tents, and even disco balls) between people all around the 
city where one lives. With its telltale motto "Discover what people are sharing on your neighborhood!" [20], it is a good exemplar of the communal logic of urban new media. Of course, it is hard to predict how your neighbors could react to your request regarding borrowing things, but with this app you can be certainly sure about it since there is a technological network that maintains your relations and reduces ambiguity. It is compelling to point at exactly the word "neighbor" in the motto: there are not just people who live in the same city, there're neighbors. It is important to underline because it means that technologies are not only operating to connect people but simultaneously they maintaining their ideologies about who they are. Another peculiar example of this logic is very well-known application named "Waze" [21]. It helps drivers all around the world to drive through their cities with little obstacles: traffics jams, road police, construction zones, to name only a few. Of course, drivers could use navigators, but who can guarantee that they will be really useful? With Waze car owner has such a guarantee. From whom, one may ask. From friends, application answers. "The same people as you", application continues, "solve problems together". And then, "Imagine: millions of drivers work together for common aim: overcome traffic jams and give everyone possibility to get to work on time" [21]. The most appealing motto regarding the app is "Imagine that you got millions of friends on road!'. 'Community', 'friends', 'common aim', - these words used not by scholars but by developers and users themselves. The users are active participants of the creation of alternative urban maps with their own layout that are not cross with city planners' schemes. Although they are confronting the same problem: traffic jams, it is resolved by different means and creating different networks with different ideologies. People (developers, drivers) and things (application, smartphones) assembling around problem-issue, obtain new identities through common coordinate practices: marking, tracking, mapping out. They have now become new real representations of city space (in case of digital maps on screen) as well as friends and community to each other (people).

Waze is a good example of participatory sensory networks (PSN), - concept that was created not long time ago to refer to technologically mediated digital platforms that with the help of sensors (smartphones, for instance) create representations of environments of different kinds [22]. Being of continuation of the ubiquitous computing concept [23], PSN refers to special technologies disseminating in an environment that could collect information in the wild to transport it to common knowledge infrastructure. Urban apps are wide-citied examples of PSN, some scholars even write that Instagram could also be regarded as PSN, although Instagram has no specific aim in gathering "useful" information like Waze, or Weddar (app for weather reporting from users) have [22]. PSN concept is to a great extent based on community image, where users play active participant roles in resolving issues, mainly connected with lack of knowledge problems.

Communal logic penetrates many urban new media we know today. Events like "AppMyCity", interviews with developers, newspapers articles create images of some digital technologies as important tools in resolving urban public problems and creating communities. Nevertheless, their roles as active participants are veiled that causes view of the same urban communities as they always were before technologies. It seems that communities of drivers of public commuters were always there, in the city, but had a lack of coordination. Technologies are appearing to be only the means of creating connections and representing issues, no more than that. Following Bruno Latour's ideas we can say that it is nonsense. New technologies not only help to aim the target successfully, but also 
transform the target itself [8]. "Peerby" neighbors are not equal to traditional neighbors we might see in urban history (although they are too were different). As well as communities, based on digital platforms, are changing and have challenge to old ideological communities urban scholars wrote about decades ago.

\subsection{The critical logic}

As on Maurits Escher's picture "Day and Night" where white birds flying to the right are appearing to be black flying to the left, the same transformation might be pursued in visions of urban new media. Where communal logic finds active participant users, who gather around common problem issue, critical logic depicts passive users who just follow the instructions and work unconsciously on the new digital platform economy. There are at least two foundations on which this assessment could be done: first, it is capacity of computational technologies to collect and keep information without users' aware of it. Even in classical communal new media like we told about in the previous section, one might find a basis for critical points. For instance, all of them has a feature called "passive report", when users with their smartphones automatically send data about their location through the GPS system. Passive report is very important in tracking users and for working the whole applications: for example, with the help of passive report Waze application could compute velocity of vehicles and, as a consequence, infer conclusions about traffic jams. Here we may also recall Graham and Crang's critics of app for they make users passive. People do not search for anything more, they do not come anywhere, algorithms do all job for them. Google Analytics is good case of both collecting information about users behind their back and make them passive simultaneously. With help of Google Analytics everyone (but in reality - marketers and web analysts) is able to know much about users of websites, online stores, data bases, etc. Knowledge is power, that's why this data is transformed into special Google service of contextual advertisements. It makes life of online users more comfortable, assembling different interests of users into a complex whole hooked up with the services provided online.

Computation technologies were widely used in performing control function regarding population since the time of their creation. The end of XIX saw the massive dissemination of these technologies, made to discipline people in all civilized countries [4]. In this way many new media as compliant heirs continue to perform the same functions, amplified to a great extent due to increasing computer powers. Evelyn Ruppert in her article on governmental digital databases shows how they are used to create new subjectivities of population out of tracking of transactions between the latter and UK State [24]. All transactions (arrests, tax paying, delicts and hundreds of others) are immediately put into databases to create an assembled view of the subject (made out of these transaction not with his mind, body or temper). Then, depends on computation of these transactions, this new subjects are inscribed in disciplinary practices. Although people's rights remain, not them that are important, but their, sometimes passive, transactions with the State. Again, passivity plus underhand computation is a formula of new media.

Unlike communal urban new media that can be called associational, critical logic should be seen as dissociational. Example of Baidu corporation app, tracking gathering of crowds, is good example here. Not to make people gather, to warn surround authorities to apply force, - these are functions of the app. Shadow of political issue here is very obvious since questions of dissociation is very near to questions of politics. Users, point of crowds, 
are seen as passive dots being under control. Actants in this network are not people is in cases of Waze or Peerby, but federal and local authorities, businessmen, police. Community is disappearing, the State is emerging in every level. Neomarxists are welcomed to ponder upon capitalist spirit in the shell of urban new media. The second dissociation strategy focuses not on political forces of opposition, but on terrorists. Again, let's listen to Crang and Graham: "Cities and the complex infrastructure grids within and between them, are now deemed to be central 'battle spaces' in which terrorists and insurgents who are largely indistinguishable from the wider urban background and this cannot be easily identified, tracked, or targeted" [12]. Terrorists (and also, migrants) must be quickly picked out from city background. As authors claims, American state creates a lot of projects under the title "New Manhattan Projects" to cope with terrorist threats. Terrorists have an ability to be invisible and un-trackable by standard methods, but urban new media with its increased power to compute could check out little feature to track. What are urban new media then? It is controlling and identifying ubiquitous computing systems always in work to dissociate people (terrorists from the population). People become objects of tracking and tracing, not citizens having right to the city and city space for the riots, but people to be controlled and identified.

This critical logic of seeing urban new media is not so widespread as previous one. But it doesn't mean that it doesn't exist. In some military and state projects, slips of the tongue, articles of critical urban scholars, we can see the black birds that appear to be white a second minute ago. It doesn't also mean that it only depends on point of view what to see in the app. Following Annemarie Mol we would like to talk about ontological politics, not about different perspectives [25]. We wanted to show that there is critical logic about new media that see them as tools of disassociation, instruments of control and disciplines, sources of making money. State and military power, Businessmen, and local authorities are real actants here and population of cities is regarded as passive objects.

\subsection{The cosmopolitical logic}

Unlike logic of communities and critical logic, which are quite familiar to urban studies and common sense at all, cosmopolitical one needs to be explicated in advance. Firstly, it's important to note that cosmopolitics has no direct relation to cosmopolitanism, system of ideas, assuming that whole planet Earth should be regarded as the place of cultural belonging and citizenship of people without national or regional restrictions. Instead, cosmopolitics points at the politics of the cosmos, such situation, according to Isabelle Stengers, who did much for popularizing this concept in the social sciences, where we see people and things gathered around some issue without longing or strategy of speed problem resolution [11]. Cosmopolitics is an additional dimension to politics regarding as building of common world with aim to slow down process of decision making, to doubt the principles assembly considers as good. Considering comsopolitics as important step further in political studies, Bruno Latour underlines four essential traits of cosmopolitics: presence of cosmos in cosmopolitics means way beyond human and their interests as the only relevant factors in politics, presence of politics in cosmopolitics means that there are no finite lists of entities which should be considered as relevant, cosmopolitics means departure from a priori and ready-to-use accounts of what should be done [26]. Finally, cosmopolitics are against common measure (and thus tolerance) of everybody and everything that are included in cosmopolitical assembly [27]. 
Cosmopolitical view has been yet applied to pondering upon digital platforms and their role in city in academic literature. Chilean scholars Tironi and Sanchez Criado offer one of the possible accounts regarding what smart city projects could be [28]. They show that smart city becomes catchy concept, attracting much attention from both academic and grey literature. One may easily face triumphant accounts of smart city as well as critical. It becomes an agenda of local policies of many cities all over the world. At the same time, they clearly demonstrate the experimental character of different projects under the name. Nobody knows what smart city is, where its boundaries lie, what aims does it have. Even the accounts of multinational corporations, local and federal governments, and official experts, who has a lot of interest in the smart city projects, cannot be considered as clear and solidified. In this way, it could be said that smart city project is in controversy situation. Thus, another relevant actors could be added to them with their own ways of thinking about what city is, what role of users of digital platforms, and what aspects of cities should be considered as important. The authors assume that all along with institutionalized and industrial-led projects funded by big corporations and federal and local authorities amid relevant actors one may point at "grassroots collectives, seeking to "open up" the city through different forms of urban sensing devices" as well as activists (permeated by hacker ethos), making efforts to make "available other sorts of experiences and urban sensitivities", which usually are invisible to authorities' projects. The examples they refer to are digital collaborative projects (like collaborative mapping) where "people devote to jointly creating, maintaining and sharing all kinds of data" about urban space [28]. OpenStreetMap project, where people freely draw paths and mark point of interests of all kinds (for instance, streets for cycling), is one of them. DIY sensors created to track objects that could not be considered as usual in smart city (atmospheric toxic chemicals, electromagnetic radiation, etc.) or show spaces regarding political movements are another epitome of cosmopolitization of smart city project [28]. Third compelling piece is opensourcing of urban space, where digital infrastructures are open to change from different interested and skilled users [38]. Anyone can create code for making apps or soft for tracking or sensing anything in urban space.

Although Tironi and Sanshez Criado's article should be treated as outstanding due to amount of literature authors colligated together, they consider cosmopolitics in urban new media only from one angle while ignoring others. We would like to indicate other embodiments of this logic. It could be seen somewhat counterintuitive, but well-known Foursquare, Trip Adviser and some other applications are created based on cosmopolitical logic. They create an informational infrastructure where both voices of local citizens of some places and experts can be heard. Places (touristic, most of all) are seen through assemblages of accounts from different people and sources. Friends' views could be taken into account during choosing the place to go together along with special communities' (café, restaurant amateurs), expert papers from press, and opinions of people who live nearby. Unlike communal logic, there are no certain types of people who are going to be associated with each other. Unlike critical logic, the main aim of these apps is not to sift people or to control them but to assemble different accounts from manifold of people to understand places all over the world. Such new media as Instagram should be also considered as cosmopolitical because one can meet there not only official pages of institutions and projects, but also photos of all people who would like to add certain tags to them. One can make their own representations of the world and its fragments to be demonstrated to 
other people. And, in sum, we can get a lot of multiple representations about objects and institutions. By the way, it is a good way to consider difference and multiplicity of some important concepts, institutions and events in society: to convoke them in one heterogeneous assemblage of Instagram photos.

Cosmopolitical agenda became important also for scholars themselves. We're talking not only about recently published groundshaking volume of I. Farias and A. Blok [26], but also about other academic projects. For instance, scholars from Italy and Sweden P. Ciuccarelli, G. Lupi and L. Simeone write in their book about data city that their "assumption is that by conducting an analysis of these people-generated landscapes - more specifically, of data sets based on information extracted from social media - we can recognize multiple interpretations of the city as they emerge, overlap, and influence each other and as they unfold from users' mental representations and spatial experiences of city spaces" [27]. But it is important to note that cosmopolitics here is not only vision on scholars' side - it is embedded in the technological infrastructure of social media themselves, that is, in API. The latter permits downloading, analyzing and visualizing plenty of users' data. It also gives possibility to put them all in one surface (but not with the same measure) to see complex and intricate nature of urban spaces we live in.

\section{Conclusion}

To conclude, it will be great to return to Monotown case we're told about in the beginning of the paper and to dream up a little bit. What logics of new urban media will be embedded in this project? Maybe it will be communal logics and we will have something like 'Boston Citizen Connect' or Indian "I change My City" applications with certain function of Waze to help people from monotowns to make urban infrastructure better. Or it may be (we hope not) will be critical logic where "Vkontakte"- based platform will become part of governmental measures (recalling Ruppert's data bases) to control the monotown population (with different level of efficacy). Or maybe it will be cosmopolitical one where activist and local business projects will be hear as well as federal and local authorities', where monotown specific urban things will be regarded with the same attention as governmental plans. Anyway, it will be certainly only beginning of the story of urban new media.

\section{References}

1. Monogoroda "VKontakte": polnost'iu utrachen kontakt vlasti s naseleniem [Monotowns "Vkontakte": contact of the state with population is absolutely lost]. Available at: http://regnum.ru/news/economy/2069576. html (accessed: 10.12.2016). (in Russian)

2. Cherez prohodnoi dvor "VKontakte" ne reshit' problemu monogorodov Rossii [With help of public thoroughfare "Vkontakte" we can't resolve the problem of Russian monotowns]. Available at: http://regnum. $\mathrm{ru} / \mathrm{news} / 2069556 . \mathrm{html}$ (accessed: 10.12.2016). (in Russian)

3. Venturini T. Diving in magma: How to explore controversies with actor-network theory. Public understanding of science, 2010, vol. 19, no. 3, pp. 258-273.

4. Manovich L. The language of new media. MIT press. 2001.

5. de Souza e Silva A. From Cyber to Hybrid: Mobile Technologies as Interfaces of Hybrid Spaces. Space and Culture, 2006, vol.9 ( March 2006), pp. 261-278.

6. Galloway A. Intimations of everyday life: Ubiquitous computing and the city. Cultural Studies, 2004, vol. 18 (Feb. 2004), pp. 384-408.

7. Wang D., Park S., Fesenmaier D. The role of smartphones in mediating the touristic experience. Journal of Travel Research, 2012, vol. 51 (April 2012), pp.371-387. 
8. Latour B. On technical mediation. Common knowledge, 1994, vol.3 (Feb. 1994), pp. 29-64.

9. Mol A. The logic of care: Health and the problem of patient choice. Routledge, 2008.

10. Tresch J. Technological World-Pictures. Isis, 2007, vol. 98 (Jan. 2007), pp. 84-99.

11. Stengers I. The Cosmopolitical Proposal. Making Things Public: Atmospheres of Democracy. Eds. B. Latour and P. Wiebel. The MIT Press, 2005, pp.994-1003.

12. Graham S., Crang M. Sentient cities: ambient intelligence and the politics of urban space. Information, Comunication and Society, 2007, vol. 10 (June 2007), pp. 789-817.

13. Woolgar S. The turn to technology in social studies of science. Science, Technology \& Human Values, 1991, vol. 16 (Jan. 1991), pp. 20-50.

14. Latour B. We have never been modern. Harvard University Press, 2012.

15. Crowd control? Baidu Has an Algorithm for That. Available at: http://blogs.wsj.com/ chinarealtime/2016/03/23/crowd-control-baidu-has-an-algorithm-for-that (accessed: 10.12.2016).

16. Silva T. et al. A picture of Instagram is worth more than a thousand words: Workload characterization and application. Distributed Computing in Sensor Systems (DCOSS). IEEE International Conference. IEEE' 13, 2012, pp. 123-132.

17. Carah, N., Shaul M. Brands and Instagram: Point, tap, swipe, glance. Mobile Media \& Communication, 2016, vol. 4 (Jan. 2016). 70.

18. Zorbaugh H.W. The gold coast and the slum: A sociological study of Chicago's near north side. University of Chicago Press, 1983.

19. A contest for the world's best urban app. Available at: http://www.appmycity.org/ (accessed: 10.12.2016).

20. Peerby application. Available at: https://www.peerby.com (accessed: 10.12.2016).

21. Waze application. Available at: https://www.waze.com (accessed: 10.12.2016).

22. Xiao-Feng Xie, Zun-Jing Wang. An empirical study of combining participatory and physical sensing to better understand and improve urban mobility networks. Transportation Research Board (TRB) Annual Meeting. Washington, DC, USA, 2015.

23. Weiser M. The computer for the 21st century. Scientific American, 1991, vol. 265 (March 1991), pp. $94-104$.

24. Ruppert E. The governmental topologies of database devices. Theory, Culture \& Society, 2012, 29 (April-May 2012), pp. 116-136.

25. Mol A. Ontological politics. A word and some questions. The Sociological Review, 1999, vol. 47, S1, pp. 74-89.

26. Latour B. Whose Cosmos, which Cosmopolitics. Common Knowledge, 2004, vol. 10 (March 2004), pp. 450-462.

27. Farias I., Blok A. Introducing urban cosmopolitics: Multiplicity and the search for a common world. Urban Cosmopolitics. Agencements, assemblies, atmospheres. Eds. A. Blok and I. Farias. Routledge, 9, 2016.

28. Tironi M., Sánchez Criado T. Of Sensors and Sensitivities. Towards a Cosmopolitics of "Smart Cities"? TECNOSCIENZA: Italian Journal of Science \& Technology Studies, 2015, vol. 6 (Jan. 2015), pp. 89108.

29. Ciuccarelli P., Lupi G., Simeone L. Visualizing the data city: social media as a source of knowledge for urban planning and management. Springer Science \& Business Media, 2017.

For citation: Rudenko N.I. New media and cities: three logics of investigation and implementation. Vestnik SPbSU. Sociology, 2017, vol. 10, issue 1, pp. 115-125. DOI: 10.21638/11701/spbu12.2017.108.

Received 13.12.2016

Accepted 26.12.2016

Контактная информация

Rudenko Nikolay Ivanovich — PhD, senior research fellow; associate research fellow; nckrd@mail.ru Руденко Николай Иванович - кандидат социологических наук; старший научный сотрудник; ассоциированный научный сотрудник; nckrd@mail.ru 